\title{
CAPITALISM AND RELIGIOUS BEHAVIOR: The Case of Tumpang Pitu Gold Mining in Banyuwangi
}

\author{
Anang Gunaifi Alfian \\ Center for Religious and Cross-Cultural Studies, Gadjah Mada University \\ E-mail: ananggunaifialfian@gmail.com
}

\begin{abstract}
In the discourse of globalization, religious agency plays an important role ranging from supporter to the opposition of the globalization. However, the understanding of globalization should involve its encounter with localities. In religious studies, religious responses can be an entry point to see how global issues impact the practice of religion. Selecting the case of the conflict over gold mine at Tumpang Pitu near Banyuwangi, East Java, as a place of conflict and encounter between capitalism and religious behavior is significant in portraying the dynamics within religious agency. Here, capitalism is discussed as the popular term among the rejecters of the mining, together with religious behavior as expression, logic, attitudes of religion. Therefore, this research is aimed to investigate the effects of gold mining project Tumpang Pitu toward religious behavior. To emphasize the study on the working of global issues and religious locality, the research employed ethnography of global connection proposed by Anna L Tsing (2005) added with religious account. The result shows that the conflict within traditionalist religious affiliation as seen in the debate over its position on the mine, a conflict extending from the grassroots to the highest level, reflects the struggle within Indonesian Islam over effective and ethical relations with global capitalism.
\end{abstract}

Keywords: Tumpang Pitu; mine; religious; behavior, capitalism, traditionalism, global; local; capitalism.

\section{INTRODUCTION}

This paper is based on a field research project on the interconnection between business practice and local empowerment in Tumpang Pitu Gold Mining project in Banyuwangi, East Java, Indonesia. The gold mine has become an arena of conflict because some local communities have rejected it as natural exploitation which negatively affects their social and environmental livelihood. Meanwhile, the government has supported the gold mine for the benefit of national development. In this case, the local religious institutions tried to formulate a response against the mining with religious legitimation. Thus, the conflict lies in the contestation of ethical responses to the impact of the mine on the surrounding environmental and societal life. My interest is to develop an approach to this question of religion and globalization. In religious 
studies, in which the religion as the locus, the existence of globalization opens a wider possibility to see features of religion as a globalized entity. The interest of scholars to see this encounter between religion and globalization has been quite pervasive. Scholars have studied this commonly accepted word such as Vasquez (2003: 35) who saw the work of globalization on religion as reattachment in a new space-time configuration after unbinding it from its traditional references to the extreme imagined trajectory of Samuel Huntington (1996) in his shocking work Clash of Civilizations. Religion also plays a role in rejecting evil globalization and turn it to a new global world order as what the Pope John Paul II stands for the anti-debt movement against neoliberalism and calls for "global" human rights instead (Lechner, 2005: 110-123). Thus, the attachment of religion on global conditions and global configurations is what inspired me to observe the global connection of religion with, particularly capitalism.

In particular, the theoretical framing is inspired by Anna L. Tsing's work Friction: Ethnography of Global Connection (2005) that studies what she calls "friction" works in global setting. Her work in the Meratus Mountain of South Kalimantan in Indonesia is inspiring because she proposes an alternative way to expand ethnography to global scale. She found out that the interconnection between local empowerment and struggle and the business practice is what characterizes the rainforest in Indonesia. As opposed to the single-mindedness of cultural explanation, her Ethnographic approach is as found in Clifford Geertz's idea "the importance of cross-cultural and long-distance encounter in forming everything we know as culture (2005: 4). The reason she develops "friction" as the central concept in her analysis as she argues is that friction is what makes motion possible. Thus, locality, behavior, belief as a constituent of culture is in motion only with the presence of friction. Thus, differing herself from classical ethnographer, she takes the travel of this "friction "as the object of her research. However, I will use the idea of Tsing's friction specifically to analyze religious behavior in relation with capitalism to signify the religious narrative of my research.

This work, therefor, attempts to see the connections of many interests especially with the presence of religious involvement and global capitalism in the issue. The example of religious presence can be seen in the issue of 'fatwa haram' (religious determination of the forbidden status of gold mining) by Lajnah Batsul Masail of Nahdhatul Ulama (NU) of Banyuwangi in which it has not worked well because of frictions and conditions that cause religion and capitalism to negotiate productive perspectives. This insignificance of the fatwa, as I analyzed, has to do with the dynamics of religious behavior in 
dealing with capitalism. I also analyze another form of religious aspiration to the mine, that is pengajian (religious preaching) conducted by an affiliatedNU youth activism which condemned the mine as ecologically destructive and capital-oriented. Three questions are being discussed here in this work. (1) How has Indonesian traditionalist Islam offered an ethics of acceptance and/or resistance to Tumpang Pitu gold mine project?; (2) What kinds of religious behaviors have traditionalist Muslim communities used in their responses to the project and why?; (3) How does traditionalist fiqh analyze capitalism especially in its relation to ecological exploitation? And how does traditionalism understand the interaction of local-global capitalism?

The discussion encompasses the literature of religion, capitalism, and globalization as well as traditionalist behavior toward the state in the historical record. First of all, it is important to involve two prominent figures, Karl Marx and Marx Weber, to see the intersection between religion and capitalism. These two thinkers of the 19th century give a great contribution to this discussion. Karl Marx concerns deeply on capitalism in his works while Max Weber contributes to the sociology of religion. For the need of this research, their views on religion can be a starting point. The famous phrase of Marx "Religion is the opiate of the masses" is responded by John Raines on Marx on Religion (2002), by saying that what Marx refers in his view on religion is exclusively to the state religion of Lutheranism Germany and the Church of England in Great Britain (Raines, 2002: 9). He summed up that religion for Marx is both the voice and the protest of the oppressed and the suffering itself (2002: 6). Hereby, we can understand that what Marx fought is actually a kind of religion that trapped only in the illusionary world without an ability to understand how human being works. Raines continued to argue that what Marx said is actually his criticism toward religious uncritical view on the instinctive value and human dignity. Therefore, when religions do not become the fighters for human dignity, they will turn into the merely opiate of the masses unless religions are able to recontextualize Marx's idea of social power of production into global context (2012: 13).

On the other hand, Marx Weber comes up with different view in seeing religion not as an "effect" but as a "cause" of economic and social lives as documented in what is called "Weber thesis", attributed to him from the essay The Protestant Ethic and the Spirit of Capitalism first published in 1930. In contrary to Marx who says that all human institutions are basically based on economic principles, he argues that modern capitalism is created from developing human rationality of worldly religious duties which had a precedent in Benjamin Franklin's use the Bible's verse to Luther's idea of 
"calling", as well as through its Calvinist interpretation. Here Weber criticizes Karl Marx as he said;

Manner of life so well adapted by peculiarities of capitalism.... had to originate somewhere. And not in isolated individuals alone, but as a way of life common to whole groups of men. This origin is what really needs explanation. Concerning the doctrine of the naive historical materialism (The creed of Marx and Engels), that such ideas originate as a reflection or superstructure of economic situations... in the country of Benjamin Franklin's birth (Massachusetts), the spirit of capitalism was present before the capitalistic order (Weber 2001: 20).

The argument is somehow supported by his analysis of how New England has developed capitalism faster in 1632 with the presence of religious preachers rather than other Southern parts of America with large capitalist for business motives (2001: 20). Thus, the difference between Weber and Marx can be known for their different use of cause and effect perspective toward religion and capitalism.

Another recent scholarship on capitalism comes from a historian, Joyce Appleby, who see capitalism from a historical perspective. In her work The Relentless Revolution: A History of Capitalism. She argues that capitalism is a cultural system where its definition cannot be separated from its encounter with custom, politics, and cultures that impinges its development (Appleby, 2011:24). As she put it, the history showed how Cheng He under Ming dynasty of China initiated the trade travel to Atlantic nations but could not last from more than three decades, while Portugal and the rest of European countries rushing its expedition in search of global trade. This is, among other reasons, because the Chinese had been politically more strict and lack of evangelical spirit than the European countries (2001: 14). In short, her opinion on the development of capitalism as culture and its relentless revolution through contact with varieties of cultures and politics is what made capitalism continuously define its existence and does relentless revolution. Therefore, her study of how cultures and global interaction define the ever-changing capitalism meets my research discussion on capitalism and religious behavior.

As the research takes an exploratory study on the relation between local religion and global issues, the discourse of religion and globalization helps to understand how they are related to each other. As there are enormous perspectives of the characteristics of globalization and how it relates to religion, the work of William Stahl (2007) elaborates the real impact of modern globalization on cultures as well as causes of religious opposition 
toward the force. He mentioned five common dimensions of globalization which are: first, the revolution in communication and transportation technology which begun in 1950s' invention of television and jet-travel and intensified by the appearance of internet, computers, cellular telephones in 1980s and 1990s. Second, political and military dimension stated by the fall of the Soviet Union and the end of the Cold War sustains American hegemony leading to an attempt to control world oil reserves, the rise of China and India as major economic and military power, and Iran strengthened their power too. Third, the establishment of international infrastructure such as the International Monetary Fund, the World Bank, the World Trade Organization gave birth to the Washington Consensus in the 1980s to foster free market ideology. Fourth, the environmental exploitation by industrial needs. Fifth, on the effect of religion and cultures. However, Stahl argues that the modern globalization emphasizes the "congruences and over-determination of all five of these dimensions on a planetary scale" (2007: 339). Furthermore, the variety of religious responses to of globalization can be seen both negatively and positively. Negative responses range from softer rejection, opposition, and, to the most extreme, resistance. The anti-debt movement is the example of religious rejection to globalization. It is initiated by the Church. Basing it on the interpretation of Leviticus 25:10, the Pope John Paul II wished to restore human harmony and to relieve burdens of poor countries (Lechner, 2005: 120). An extreme resistance even takes form in public terror like the spread of Jewish protocols in Japan media which affected a religious sect Aum Shinrikyo in 1995 to release poison sarin gas on the Tokyo subway, killed twelve people and sent thousands to the hospital (Goodman, 2012: 146). Meanwhile, positive responses from a brighter hope for its cooperation with global development goal because some faith representations have involved in a partnership with World Bank and International Monetary Fund to discuss the economic models for developments to end poverty and fight for social justice (Marshal, 2008: 225).

In addition, the author also takes the categorization of NU's behavior by Fealy in his work Ijtihad Politik Ulama (2003), regarding the relation between NU versus the state. The behaviors are divided into two: accommodative and militant. It is based on his specific period of study during Soekarno's presidency. In the first period of 1957-1961, NU carried out accommodative politics especially for being a political party and occupied an important position in Soekarno's parliamentary cabinet known as Kabinet Gotong Royong as advisors and supporters of Soekarno's guided democracy. Meanwhile, militant behavior showed up by the following period of 1963-1967 as a criticism of the negative impact of accommodative behavior. According 
to Fealy (2003), among the negative effects of accommodative behaviors are the rise of corruption among NU leaders because lack of professionalism and a great amount of maladministration, as well as the rise of moral degradation among ulama as seen in the phenomenon of hubbul jah (prioritizing personal interest to get a social and political status higher than the organization's goal for social welfare), and some Ulama's relation with communist figures, and entertainment artists (2003: 255;309).

On the other hand, the militant behavior initially appeared because some NU ulama and youth felt threatened by the growing political influence of the communist party. Thus, militant behavior was meant to show physical strength of NU that was prepared for any threats and confrontation with their enemy: Indonesian Communist Party. One of the NU's bodies created for that purpose is BANSER (Barisan Serba Guna Ansor). This is a paramilitary organization in NU whose duty is to give physical protection for the party and all their members. Thus, while the dynamics of the organization cannot be simplified, the study has identified two tendencies of NU's behavior which are accommodative and militant. Besides, other studies on the characteristics of the Nahdlatul Ulama (NU) vis-à-vis the state has inferred tow points: fiqh is important as religious argumentation in traditionalist behavior, and NU's involvement in the political and social sphere is for religious purposes. The former can be found in the woks of Bruinessen in a chapter on the function of figh in NU (994: 196-204), Fealy in her constructive discussion on religious political thought of NU (2003:57), and Bush's argument that the uses of politics by NU is to pursue its religious ends and saw that the spirit of khittah (making NU as social activism, community empowerment, and social economic welfare) has been confirmed by NU's civil society discourse and activism (2009:198). Feillard (1999) acknowledged a strong concern of NU to work for the prosperity of the people based on the religious ideology when he said, "their purpose (NU) is not at all to leave all forms of political role, and nor to support the government political party, Golkar" (1999:236).

The second point of the characteristics is found in Bruinessen (1994) when he saw the lack of discipline inside the organization in which is because of its decentralized power characters where some local figures and groups within NU might have a greater influence than the higher hierarchical structure of the organization. Therefore, it relies on the consolidation among the bodies in each level and it requires the independency to the state. The consolidation, then, involves religious motives in both political and social action. Fealy (2003) also saw that the NU's behavior during Soekarno, that is, to compromise communist involvement in the Soekarno's cabinet, is a strategy 
to secure traditionalist interest, while Bush (2009) specifically argued that all the political behavior of NU is targeted to counter the modernist influences. According to her, NU has used politics for religious ends (2009:14). By this, she intended to contrast traditionalist religiosity and modernist religiosity. Feillard (1999) also argued that NU's apoliticism in the khittah declaration was actually a form of its return to the initial pragmatism in which it did not necessarily leave politics. Instead, it is a strategy to defend their identity from government repression (1999: xiii). Therefore, in relation to the political participation through history, the militant and accommodative behavior of $\mathrm{NU}$ is actually based on the religious purposes derived from the concern of traditionalist fiqh and their strong religious motivation. Then, this study looks at the two behaviors in the case of the mine and relate it to the discussion of traditionalist's ethical response in two forms i.e NU's activism and the reasoning of fiqh.

The discussion over these questions is based on three key points as theoretical framework to give direction of the research discussion and to answer the research questions including Tsing's concept of "friction", the behavior, ideology, and ethics as well as authority and resistance. To foster the ethnography of global connection, friction is used as the metaphoric concept of the analysis. Tsing (2005) defined friction as the awkward, unequal, unstable, and creative qualities of interconnection across difference (2005: 3). She comes to this definition after rethinking the messiness of interactions in her case result from questions like; what happened when Japanese traders buy Indonesian trees, when army officers make deal with nature lovers, or when university students sit down with village elders. Then, he argued that "the messy and surprising features of such encounters across difference should inform our model of cultural production" (2005: 3). And the friction is those encounters and interactions that made cultures always co-produced. Moreover, the concept of friction is significant in two things; first, the friction can lead to a new arrangement of culture and power through heterogeneous and unequal interactions. Second, it tells the importance of interaction in defining movement, cultural form, and agency (2005: 5-6). In accordance with the research question on the relation between capitalism and religious behavior, the concept of friction will serve more as an approach of this research to explore some issues happening around the interactions between local empowerment and the global capitalism represented by the gold mine such as the issues of development and an ecology, and local and global capitalism in the field.

While the metaphor of friction is intentionally used as the approach to look 
at the relations of capitalism and religious behavior in its global connection, the Weberian concept of verstehen is used to look at the religious motivation behind religious action. Hence, the term religious behavior is proposed here for its sociological significance. The term verstehen, as derived from a German word, means "understanding". the concept is a conceptual scheme used by Weber oriented toward the explanation of the nature and determinants of social conducts (Tucker, 1965: 157). Then, the understanding of the social conducts or social behavior can be gained by acknowledging its social significance and its motivation of the actions. However, not all behaviors or action belong to the social conduct. The social conducts here refer to any social action or social behavior which is of a social nature and is sociologically meaningful (1965: 158). As emphasized by Tucker, the concern of sociologist as indicated in Weber's work is the behavior which results from relationships with other individuals as opposed to unsocial behavior of an individual, such as behaviors that are strictly reflective, mystical behavior, and those from psychophysical processes, rather belongs to psychological or biological analysis (1965: 159161). Thus, the religious behavior used in this study is to indicate a social action which results from and uses religious motivation in their action as well as to indicate its participation in a social condition. In this study, the religious behavior is aimed to be rationalized not by making ay categorizations but by learning the social situation and religious motivation that affect that behavior.

Furthermore, the rationalization of religious behavior can be considered from its practical implementation of ethics as a perception of what is good and evil conduct. As this study aims to point out the ethical responses resulted from the religion's encounter with global issues, traditionalist ethics is necessary to discuss. In this context, we see ethics as an extension of morality of Islam and a method of discernment of the moral value. Islam as a religion has distinguished the good from the evil. For instance, it upholds the value of humanity, freedom, and social justice and is against destructive behavior, arrogance, ignorance of the poor. However, some interpretations of whether certain action such as the gold mining activity is good or evil needs an ethical analysis. According to Daniel C. Maguire (1991: 34), "ethics is the art/science that seeks to bring sensitivity and method to the discernment of moral value." To bridge the enormous number of moralities that can be different and conflicting to one another - which usually termed as relativism-as religions, traditions, cultures differ in their perspectives over a problem, he emphasized the definition of ethics as sensitivity and method to discern the moral values. The sensitivity is addressed presuming that every human behavior is ethical because a certain behavior affects other human so that a moral dimension in each behavior should not be avoided. While as a method, ethics is made up 
by certain consideration of its inquiry albeit there is no guarantee that the agreed decision is the true ethical choice (1991: 35). In regard to traditionalist Islam, the ethics is a discernment of the morality of Islam, while the morality simply means the way of life and the principles of good and bad in Islamic teachings. Furthermore, in the Islamic tradition after the life of the prophet, the ethics has developed in the body of fiqh often referred as a space for the exercise of intelligence because the practicalities of the ethics involve a process of rationalizing the moral values.

Furthermore, the account of religious behavior, when put as the local empowerment to the gold mine existence, implies its resistance to the appropriation of the mine by the government. It also depicts the power relation between the authority of the government and the subordination of local resisters. To analyze the power relation beyond the resistance, we use the study of "everyday forms of resistance" by James C. Scott (1989), with the thesis argument as follows;

much of the politics of subordinate groups fall into the category of everyday forms of resistance, that these activities should most definitely be considered political, that they do constitute a form of collective action, and that any account which ignores them is often ignoring the most vital means by which lower classes manifest their political interests (1989: 33).

By this definition, Scott analyzes less-noticed patterns of resistance into a unit of category. And he urged to consider them as much political as the obvious form of resistance like revolutionary movement and an armed rebellion. According to him, the everyday forms of resistance, despite its diverse manifestations, are characterized by their aim to thwart some appropriation by superior class or the state, invariably in a quiet, disguised, anonymous, often undeclared form of resisting claims (1989: 37). Some of the everyday forms of resistance are such as actions like poaching, foot-dragging, desertion, arson, sabotage, as well as any other possible forms of resistance that have the same purposes. In this study, I use the concept of every day resistance to argue for the existence of two authorities in relation to the local resistance especially in the event of pengajian where religious aspiration was used as both a criticism to the authority of the government and a call for loyalty and being disciplined in the traditionalist way of being religious and ethical including in form of resistance, or in other word, to defend the authority of traditionalist Islam as the practiced religion.

Another important concept to delve into what makes people resist to an 
exploitative project is moral economy. Furthermore, Scott (1976) also studied that in any pre-capitalistic society, they have a concept of moral economy. His observation on peasant life of South East Asia especially around the issues of exploitation and rebellion is actually a question of peasant conceptions of social justice, rights, and obligations, reciprocity. Then, he argued that the study of moral economy should begin with the domains of economics and ended with looking at the people's culture and religion (1976: vii). This concept of moral economy will be more relevant when used not only to reductively argue that the subsistence ethic which characterized the moral economy of the peasant is rooted in the economic practices, and social exchanges among peasant societies (1976: 6) - which what Scott defended for and inspired by Marxist economic determinism - , but to use it to explore the power relation between the moral authority of the people, and the government authority of related resistance. This way of looking at the moral economy of the local resistance is able to explain the trajectory of this study, which is to see the traditionalist ethical response - representing the authority of the local's practiced religionto the gold mine and the government supporting it and also to put the local impacted people under the influential interaction of global connection which takes place in the middle of two authorities: the traditionalist Islam and the Indonesian government. In this context, religious authority works as ethical response to the mining in form of its institutionalized decision conducted by the fatwa board representing the moral economy of the people and strengthen the local empowerment against the extractive mining when the mining is supported by the government and fueled by global economic mechanism. Rather than measuring how significant is the religious authority in bringing the ethical response to seize majority intention and intervene the economic policy which is related to the political realm of religion and abstract ides of the religion-state discourse, this study chooses to focus more on the interconnections on the practice of religion as its entanglement with the government, the local empowerment, the ecological damage, and global issue of capitalism. This is based on a qualitative exploratory research as explained by Cresswell (2007: 24). In this light, this research explores the power relation as well as comprehending the historical and social values of the traditionalist Islam and the discourse on capitalism, and also put the concept of ethnography of global connection in the analysis.

\section{CHRONOLOGY OF GOLD MINING IN TUMPANG PITU}

The problem occurred during the given period. There are three distinct political and social periods through which the conflict has developed. This 30-year history can be divided into three periods; (1) potential of gold containment in 
New Order Regime, (2) local resistance and opposition through fatwa, and (3) the birth of religious-based environmental activism. The plan of gold mining was initiated around 1980-1986 when a group of geologists called Lebong Tandai Group mapped the potential and prospect of mineral resources in Jember as well as in many other areas of Bali, Lombok, Sumbawa, Flores, and Timor (Qodim, 2012: 216). Under the New Order Regime, the government supported the plan by issuing a permit called Kuasa Pertambangan (KP) to Hakman Group including the allowance to conduct surveys and exploration of the potential. The benefits are such as building infrastructures, and increasing PAD (Local Budget Income), and creating job opportunities for local people. On the other hand, the damage of the environment can be a serious impact because the location is in the areas of national conservation land (2002: 221). However, the government will increase local income has to deal with the resistance from the villagers around the areas of mining who feel that the mining will endanger the environmental stability in which they live. Moreover, there had previously been a demand from the villagers to grant them rights to access the natural resources as their source of living. These existing problems create a complicated situation that later influences the resistance of gold mine in Banyuwangi.

In 2009, a response came from Nahdlatul Ulama Organization of Banyuwangi. It was attended by two hundred religious figures and resulted in a declaration that gold mining in Banyuwangi was religiously forbidden because it brings more harm than good. The discussion was conducted on March $15^{\text {th }}, 2009$ through formal religious board called Lajnah Bahsul Masail in ponpes (Islamic Boarding School) of Nurul Huda, Muncar. (Ningtiyas, 2019: 66). However, it was not delivered to the local government as an aspiration and thus could not influence the government policy toward mining. There are reasons behind this failure such as the result was not supported by all religious figures, and there is a national political interest to support the mining. This position of religion in this situation is uncertain. The uncertainty is seen in the official local NU who were agreed to oppose the establishment of mining. Meanwhile, some of its members supported and personally benefitted from mining. Thus, this ambiguity indicated uncertainties and multi-layered interpretation toward the mining. Some NU members in Pesanggaran district rejected the mining while the rest of them support it. The inconsistency toward the result of Bahsul Masail in 2009 became an objection to some people and activists that questions the religious role in this case.

In 2013, religious environmentalist was created by youth movement. It is called FN KSDA. The name is abbreviation from Nahdliyin Front of Sovereignty over 
Natural Resources. The emergence of this organization is basically because the concern of NU about sovereignty over natural resources and land issues as discussed in its national conferences cannot give significant voice. Then, some NU youth initiated to form an organization outside the formal structure of NU and being active in environmental and agricultural movement. FN KSDA is a grassroots organization which have increasing followers from many cities in Indonesia. Through coordination line, they become front men in land and resources conflict such as in Kendeng, New Jogjakarta Airport, and also in Tumpang Pitu Gold mining. What differentiates FN from other organization is that they bring with them religious ideologies to the problem of environments. When this research was written, the religious authority seems to be in a dilemmatic position. On one hand, the religious position is politically supportive to the government, but on the other hand, the religious committee attempted to draw a clear limit in the legitimation of mining based on religious reasoning. In relation to dynamics of power relation between NU and the state, the presence of FN can be traced historically as an outcome of transformative interpretation of Khittah '26 of which is caused by the NU's behavior during Soekarno regime. The khittah '26 is a historical event held in 1974 at Situbondo National Congress as a declaration of NU to get out from practical politics and return to the spirit of the initial khittah 1926 i.e to make $\mathrm{NU}$ as a social-religious organization. Khittah itself means the foundation of thoughts, attitudes, values, and action of NU that are to be implemented by its members and the organizational decisions. The Khittah has been regarded as the revolutionary path in internal dynamics of NU.

The making of the Khittah has preceded by various problems within NU in relation to its position to Indonesian politics In Indonesia. The khittah influenced the birth of FN in some ways. First, FN was born from a progressive youth intellectual forum in LKiS Yogjakarta. The community that saw khittah as a renewal in Islamic thought to cope with social problems. Bush (2009: 95) identified them as born from the effect of the spirit for renewal in khittah decree of NU. Meanwhile, ideologically they adopted leftish Islam, not in form of Marxist but purely as a phenomenon emerging from the oppression of the Muslim, whose aim is to reconstruct the teachings of Islam to become a liberating force. Second, they integrated the spirit of militancy and proJam'iyyah at the same time. The militancy is obvious as they call themselves 'front' of Nahdliyin which implies their concern to become front liner in matters of sovereignty campaign, while pro-Jam'iyyah spirit has shown in their transformative interpretation of the khittah adopted by LKiS and the use of contextual fiqh and its manhaji approach. The main interpretations of contextual fiqh are to see it as social ethics rather than governmental positive 
law, and introduction to philosophical methodology of thought in cultures and social problems (Mahfudz, 1994: xxxvi).

\section{THE FATWA ON THE GOLD MINE}

The fatwa about gold mining in Banyuwangi was issued in 2009. It was decided by involving two hundred religious leaders in the city in a discussion held in Islamic Boarding School of Nurul Huda Muncar by Bahsul Masail Board (Ningtiyas, 2019: 66). The intention of the fatwa occurred when people around Pesanggaran district were worried about a plan of gold mining establishment near their living environment. Many NGOs had researches and analysis on the impact on the environment. On the other hand, the government was passionate to support the mining and saw that it would bring a great income to the regency. In this situation, some people were worried that its existence will affect the environment. This research found out that there are two motives why Lajnah Bahsul Masail (NU commission dealing with discussions over legal status of social and religious problem) conducted the work on the religious law of the gold mining. First, there is a demand from local people that the problem should be discussed in Bahsul Masail, and the second is the government asked for religious consideration toward the establishment of the gold mining to Lajnah Bahsul Masail (Syafaat, personal communication, March 11, 2018). There are five questions proposed in the forum; (1) What is the law for gold mining? (2) How is the law of the mining activity in Tumpang Pitu with the given context? (3) How is the law for Banyuwangi government to recommend the mining? (4) if forbidden (haram), can local income for government be the conditional reason (mujawwiz) to allow mining? (5) What is the measurement of harm/benefit of the mining?.

However, the attempt to make fatwa regarding the mining activity has not yet answered all the question due to the delay of the meeting. This delay of the decision is commonly named mauquf meaning not yet fully solved. Only three of the five questions were answered in the document of the fatwa which are; the first, the second, and the fifth question. These answered questions are about the measurement of the negative and positive side of the mining. Some keywords such as common good (maslaha) and preventive action are a priority in the religious logics conducted by Lajnah Bahsul Masail. While the two remaining questions, the third and the fourth question, are related to whether the government ought to support and take benefit from the company profit share for the sake of the local government income. Answering the first group of questions about the general law for mining, the Bahsul Masail studied the similar events happened in the past. In this context, they refer to a classical 
book Asna al Mathalib fi Syarh Raudhah al Thalib by Zakariya bin Muhammad bin Zakari al Anshari from 926 Hijriyah (equivalent to AD 1520) Volume 1: page 385 , stated that " if one does mining in his own land or public land which bears a payment or tax ( zakat), then the tax is counted with measurement of gold or silver and not that of gemstone, iron, and copper". And the second reference is based on the book called Bugyah al Murtasydin Volume 1; page 291. It tells about an activity in a country that involves digging or kind of mining should be allowed as long as it does not disturb the neighboring area.

These two references are taken to argue that the mining is initially allowed in Islam as long as it does not negatively impact the neighbors. This approach is typical of Bahsul Masail argumentation, that is taking a saying or opinions from the students of Imam Syafii or the elders who follow Syafi'i school in their works. However, after the manhaji approach introduced in 1992 to the logic of the traditionalist, the board of fatwa has attempted to contextualize the problem based on the generalization of common principle that is often found in the work of a more modern scholars such as in the book al Fiqhu A'la Madzahib al Arba'ah Volume 5: page 193. The book explains that "if a case is too difficult to the answered with classical argumentation, then contextualization is necessary by referring to the saying of the prophet: "la dhoror wa la dhiror" meaning that it is forbidden to do something that can endanger one's self and the larger people. According to the author, here are two points shown in the Prophet's saying "that a Muslim should avoid any danger to other Muslim, or that a leader should avoid any danger in his policies and prefer the law that contains larger benefits." Then the first answer is continued by finding a measurement of harm and benefit to the mining in Tumpang Pitu Banyuwangi. In short, the measurement consists of three points which are: (1) the defined common good (maslaha) is that of an obvious common good and not that of estimation and opinion, (2) the existence of common good is for the public interest not for any private and community interest, (3) and that should not be contradictory to the syaria law regulated by referent text and consensus (ijma'). These three principles are taken from the book Irsyadul Fukhul ila Tahqiqi al Haqqi min 'Ilmi al Usuli Volume 2: page 185 stating "if the maslaha (common good) is urgent, obvious, and public interest, then it is allowed. But, if only one point fulfilled, then it is not allowed."

Furthermore, we find two aspects of the fatwa. Transactional matters as capitalism and environmental consideration. The fatwa does not refer to capitalism per se but it does evaluate the case of the gold mine in terms of a kind of business ethics. Here, we argue that the traditionalist Islam defines capitalism as an ethic rather than a taken-for-granted assumption. The reason 
is the word capitalism cannot be understood in traditionalist Islam's vocabulary without its attention to reciprocal relations aimed as practices of ethics in human activities. In this case, the clarity of government role in the mining is ethically important because the idea is to respect all parties in the transaction and to create a fair, open, and healthy business that no one would feel cheated or aggrieved. In this light, the traditionalist Islam also believed the priority of the common good over individual concern. Not only the transactions that matter, but also the environment considering the impact of the transaction to common people. The transaction over the gold mine by both the business corporatation and the government is thus valued through its righteous ethic of the business and its righteous environmental consideration for the greater good.

Hence, capitalism is actually a business ethic in Islam that should include ecological consideration of its impact, and the fairness of its operation and benefit distribution. Meanwhile, when it is referred as a world economic system based itself on economic determinism philosophy, the religious understanding of capitalism is actually cannot be secular since they value the term based on theological determinism through an ethical lens unlike that of the economic determinism. In this case, the ethical lens of the fatwa makes possible of a distinction between what is good and bad capitalism. Good capitalism is when the business practice includes the ecological considerations mentioned in the arguments of the fatwa and the people's well-being, while bad capitalism is simply understood as the business practices that do not fulfill the requirements, of the environmental and societal well-being, to be called ethical.

The Transactional matter concerns on the clarity of government role in the mining. The government role in the year where Bahsul Masail was held had not been clear in term of profit share and the benefit for the local regency. In the early conduct of Bahsul Masail up to 2009, the agreement that the government would receive $10 \%$ percent of the mining profit had not been decided (Lestarinigsih and Kumalasari, 2015). Thus, the early occurrence of the mining plan puts the government in an unclear position. Gus Makky is one of the NU leaders in Banyuwangi who argues for the lack of clarity of government position in the mining transaction yet he is convinced that the mining gives a great amount of benefit for the regency. In transactional matter, he said that the committee was agreed, based on the classical references, that the mining can be built only when it is run by the government as the central controller while the private company is put under it as the partner of the government (Ali Makky, personal communication, March 20, 2018). 
Meanwhile, environmental analysis is another consideration of discussion in Bahsul Masail besides the transactional matters. The consideration showed that the traditionalist implemented their renewed methodology on seeing the environmental side by not only seeking legal perspectives form existing classical references by using qauly approach, but also utilized the principle of fiqh such as maslaha (common good) to discuss the ecological relation by using manhaji approach. Hereby, I argue that by implementing manhaji approach, the Bahsul Masail discussion is able to cope with the more contemporary social and environmental issues. The use of manhaji approach is seen in their references to modern work such as that of al Fiqhu A'la Madzahib al Arba'ah Volume 5: page 193. In this situation, they use the guidance of the author to base the decision on the common good principle when the case is hard to find in the past reference. In the case of the gold mine, Bahsul Masail implemented the manhaji approach not only by including principles of figh as the solution to the lack of ulama commentaries on the problem, but also involved local environmental analysis on the possible impact of the gold mine.

Nevertheless, the allowance of natural exploitation by Islamic fiqh is seemingly contra productive with the environmentalist movement that perceive natural exploitation is bad. This perception basically derived from the concept of Anthropocentrism that put human as the cause of the natural damage. An early scholar who noticed the relation between religion and ecology is Lynn White (1967) in his work "Historical Roots of our Ecological Crisis". In the book, he argued that the cause of the natural damage is religious (Christianity) presumption of nature as the object of human's exploitation, which actually has much similarity in Islamic concept of khalifa which means God's steward in the world. The story of Adam who was educated by God to name the rest of creatures gives impression that humans are the ones that see the nature as the object in which it is meant to be exploited by human to fulfill their needs (Bagir and Martiyam 2017: 81). This perception that put religious teaching and mythology as the cause of human behavior should instead be understood differently. According to Bagir and Martiyam (2017), "Islamic anthropocentrism" is in fact does not necessarily lead to destructive exploitation of nature, because in some interpretations human can be called as effectively a khalifa only when the human being remains the obedient servant of God (2017: 81). Therefore, the language of the fatwa does not necessarily ignorant of the environmental concern but put it as one dimension that related to other parts of human life such as social order, economic prosperity, and other things as well. In this case of the gold mine, the fatwa has related the environmental issue with economical (transactional) consideration as well which in some ways tells us that environmental concern is related other parts 
of human dimensions.

As stated in the background of the fatwa, there are two reasons behind the rejection of the mine; the waste of mining can damage the communities of fish in the sea around Tumpang Pitu that it effects to the possible loss of the fishermen and there is no balance between the gaining income from the mining for the locals and the government and the environmental damage created from the activity. Here, the environmental concern of the fatwa is related to the issue of the prosperity of both the community of fishermen and the larger Banyuwanginese. The environment is understood as a part of the dimension of life that can influence the other aspects of human life. Therefore, the damage of the sea around the area can harm the prosperity of the fishermen. Nevertheless, the reason also sees that natural exploitation can be conducted for the greater benefit of the people. By this, the tolerable exploitation of nature did not mean to be destructive, but to be utilized for the greater good. This motive seems to make sense that fiqh in traditionalist Islam is not to forbid the exploitation of nature but to critically put restrictions to the activity with such questions like what makes us want to exploit nature, who is supposed to take benefit for it, and is the activity urgent enough to be conducted. Moreover, the traditionalist Islam has their own mechanism and procedures to deal with the issues of ethical and legal judgment that made other constructions and philosophical influences are hard to get involved in the discussion. Yet, there is potential as the development of religious logics within the traditionalist has widened the room for wider participation from science and philosophical thought, albeit at practical level some obstacles become the barrier for its implementation.

\section{PENGAJIAN BY FRONT NAHDLIYIN AND THE CRITIQUE OF CAPITALISM}

FN, in such natural resource conflicts, has an important role because of their position as the only environmentalist organization that derived from, yet moved outside, the formal structure of Nahdlatul Ulama. In addition, the role of leader in FN is very central as it moves on the same culture of NU whose leader is respected as ulama or kiayi for their religious authority and charisma to its followers. This chapter analyzes the pengajian addressed by Al Fayyadl, one of their intellectual leaders in front of people in Pesanggaran who mostly oppose the mine, on February 25, 2018, and argues that pengajian is a form of indirect public protest used by FN. Then, the discussion concluded the response of Islamic ethics towards the environment in relation to capitalism. Despite the fact that it is a consistency of NU to focus on the social sphere of 
people since its 'returning to khittah 1926 ' is declared, NU allow its followers to participate in practical politics and activism outside the organization. The example is such as the establishment of PKB political party as an independent political party but is supported by many NU Ulama in 1989 and lead Abdurrahan Wahid as the fourth president of Indonesia under the party, and PMII (Pergerakan Mahasiswa Islam Indonesia), an Islamic student movement which formed in 1960 to the present that affiliate to Nahdlatul Ulama.

Under this historical fact, the pengajian toward gold mine is a form of youth activism outside the formal organization of NU. As will be seen in the following description, the pengajian contains a criticism toward the government's policy in gold mine Banyuwangi. Moreover, the pengajian is also a form of public protest to minings. It is a way to seek alternative medium for public protest especially after previous contentious events, that are, destruction of mining facilities by protesters in 2015 and the arrest of an activist, Budi Pego, for bringing communist symbol. Somehow, Pengajian by FN is a safer medium to protest and at the same time to educate people to use objective criticism rather than direct demonstration. Therefore, the role of FN leader, Al Fayyadl, here is very central because of his position as also a young kiyayi in Pesantren Nurul Jadid Probolinggo. In this pengajian, FN activism carried out is strengthened with Al Fayyadl's capacity as a religious figure or young ulama.

In the pengajian, $\mathrm{Al}$ fayyadl made some points of interpretations to the relation between Islam and ecology as follows: First, he stated that the resistance toward mining should not be based on merely the sense of belonging to nature, but it is more as an act to thank God's given creation to human by keeping it from destruction. In this position, he makes a distance to common environmentalists who dedicate their effort to love nature, but he shares the same struggle and solidarity to protect nature from human excessive exploitation. Moreover, his affiliation with environmental activism is basically a criticism toward the incapability of formal NU organization to address problems of environment. The second is an example of how the ulama of the past build pesantren (a traditional sort of Islamic boarding school) on or nearby natural resources such as Pesantren Watu Congol built on the water area and Sunan Muria built one on the Muria mount. He argued that the existence of those pesantrens is a form of natural preservation from people and colonizer who planned to exploit nature. Furthermore, he gave a contrasting picture of Indonesian today that most of his natural resources are owned by some groups and foreign investors. This act of preservation and NU historical role in defending their communities from invasion and colonization from outsider are translated by FN as the 'sovereignty problem over natural resources' and has to be prioritized 
for the benefit of the nation. The third thing is the distinctive feature of NU tradition, that is basing every problem on fiqh consideration. In the last part of the preaching, Al Fayyadl invited the audience to be rational by using religious consideration including the use of knowledge of fiqh in seeing the gold mine. In this sense, $\mathrm{Al}$ Fayyadl quoted the thought of Bahsul Masail after previously visited the leader of Bahsul Masail. His realization that fiqh is an important aspect of traditionalist NU is its position as the anchor of religious behavior including in the act of resistance.

\section{CONCLUDING REMARKS}

The traditionalist behavior which is manifested in the transformation they made in logic (using manhaji approach in legal judgment), and activism by FN (in form of pengajian) shows their engagement with global issues (i.e. capitalism). Their engagement is by adaptation to globalization through transforming their instruments, that are, fiqh and informal activism. The former is through the inclusion of manhaji approach in 1992 aimed to update the tool used in the exercise of intelligence known as figh. By this approach, they can see new problems with its wider possibility and thus shifting the approach from being a follower of the past scholarship to being the producer of a new insight. In a global-local relation, traditionalist religiosity has obviously shown its positive and critical engagement to global issues. Rather than showing radical break to globalization as what is done by sect Aum Shinrikyo in Japan, they adapt to it by updating logical means in fiqh to be more capable of coping with global issues. Although, at the same time, they make a defensive wall from the global stream through holding on to identities such as nationalism, sovereignty, traditionalist brotherhood, et cetera.

Secondly, in regard to capitalism and religion, the traditionalist in the case of gold mine acknowledge its positive potential to create people prosperity and social justice. In this case, the Weberian view can help better to answer that religion is a cause of capitalism which means capitalism is natural as it inherently part of human and religion gives a bigger role in giving motivation to generate wealth and to exploit nature for proportional human need. In this case, the religious logic of traditionalist religion revealed that there is not any avoidance to exploit nature since it is made to fulfill human need. What is forbidden by religion is a condition behind it such as when it socially harmful to the neighboring environment, when it affects to the personal psychological aspect of human e.g when human accumulate wealth for personal greed. All these reasons obviously put human as the center of above all creatures.

This traditionalist Islamic fiqh that is used by Indonesian traditionalist Muslim 
do not actually understand capitalism as similar to socialist-communist but more as an ethical misconduct. Therefore, capitalism for traditionalist is a matter of ethics. As analyzed in the previous section, both Bahsul Masail and FN activism are proved that they understand problems of capitalism through the same logic, that is ethical problem, and they turn to the same solution by the exercise of intelligence through fiqh procedure.

The latter is an innovation in traditionalist activism that is characterized by their concern on natural preservation. The innovation lies in its distinguished position from those common green movements who takes side on nature per se. As for them, nature is considered as a God's gift to human being to be exploited proportionally (taisir). In other word, FN sees 'ethical' human as the center. The ethical means a wise and good behavior to nature that is contradicting to bad and greedy behavior (ifsad). In other word, FN put human as the center or what is commonly labeled as anthropocentrism. While common environmentalist put the negative impact of human behavior to nature with the idea of environmental justice, FN sees it as an ethical project to build not only environmental justice but also social justice, and what is relatively new to such movement is their use of traditionalist instrument of fiqh. Thus, the research on capitalism and religious behavior in globalization setting unfold three findings. First, the religion is adaptive to globalization in form of its logic and activism. Second, capitalism can be regulated in cases of ethical misconduct or potential harm. Third, through frictions around the case of Tumpang Pitu gold mine, the recent movement of FNKSDA and the transformative logic within traditionalist Islam can be well understood as the result of the interaction among global connections where the religion is urged to rethink their ethical stance.

\section{REFERENCES}

Appleby, J. (2011). Relentless Revolution: A History of Capitalism. New York: W.W Norton \& Company.

Bagir, Z. A. and Martiam, N., (2017). "Islam: Norms and Practices". In Jenkins, Willis; Tucker, Mary; Grim, John (Eds) Routledge Handbook of Religion and Ecology. New York: Routledge.

Bruinessen, M. V., (1994). NU Tradisi, Relasi relasi Kuasa, dan Pencarian Wacana Baru. Yogyakarta: LKiS.

Bush, R., (2009). Nahdlatul Ulama and the Struggle for Power within Islam and Politics in Indonesia. Singapore: ISEAS Publishing. 
Creswell, J. W., (2007). Qualitative Inquiry and Research Design: Choosing Among Five Approaches. USA: SAGE Publications.

Fargnoli, M., (1991). On Moral Ground: The Art/Science of Ethics. New York: The Crossroad Publishing Company.

Fealy, G., (2003). Ijtihad Politik Ulama: Sejarah NU 1952-1967. Yogyakarta: Lkis.

Feillard, A., (1999). NU vis-à-vis Negara. Yogyakaeta: LKiS.

Goodman, D., (2012). The Paranoid Apocalypse: A Hundred-Year Retrospective on The Protocols of the Elders of Zion. Katz, Steven T., Landes, Richard Allen. USA: New York University Press.

Huntington, S., (1996). Clash of Civilization and the Remaking of World Order. USA: Penguin Book.

Lechner. (2005). "Religious Rejection of Globalization" in Mark Juergensmeyer [Ed]. Religion in Global Civil Society: Religious Rejection of Globalization. USA: Oxford University Press.

Lestariningsih and Kumalasari. (2015). Kontribusi Pengetahuan Lokal dalam Tata Kelola Sumeber Daya Alam di Kabupaten Banyuwangi. Draft KSI.

Mahfudz, S., (1994). Nuansa Fiqih Sosial. Yogyakarta: LkiS.

Marshall, K., (2008). "Religion and Global Development: Intersecting Path" in Thomas Banchoff (ed) Religious Pluralism, Globalization, and Politics. USA: Oxford University Press.

Nasr, S.H., (1968). Man and Nature: The Spiritual Crisis in Modern Man. London: Goerge \& Unwin Ltd.

Ningtiyas, I., (2019). Menambang Emas di Tanah Bencana. Yogyakarta: Resist Book.

Qodim, A., (2012). Ekologi Politik Pengelolaan Taman Nasional Meru Betiri Kabupaten Jember dan Kabupaten Banyuwangi Era Reformasi Politik Nasional. Graduate Thesis, Institut Pertanian Bogor.

Raines, J., (2002). Marx on Religion. USA: Temple University Press.

Scott, J. C., (1976). The Moral Economy of the Peasant. London: Yale University Press.

(1985). Weapon of the Weak: Everyday form of Peasant Resistance. London: Yale University Press.

Stahl, W., (2007). "Religious Opposition to Globalization" in Beyer, Peter and Beaman, Lori (Eds) Religion, Globalization, and Culture. Boston: Brill Publishing. 
Tsing, A. L., (2005). Friction: Ethnography of Global Connection. UK: Princeton University Press.

Tucker, W. T., (1965). Marx Weber's Verstehen. Taylor \& Francis, ltd. The Sociological Quarterly, Vol. 6, No. 2, pp. 157-165. Http://www.jstor.org/ stable/4105245.

Vanquez, A. M., (2003). Globalizing the Sacred: Religion across Americas. USA: Rudgers University Press.

Weber, M., (2001). The Protestant Ethic and the Spirit of Capitalism. New York: Routledge Classics.

White, L., (1967). The Historical Roots of Our Ecological Crisis. American Association for the Advancement of Science. Science New Series, Vol. 155, No. 3736, (Mar. 10, 1967), pp. 1203-1207. 